\title{
Characterization of blast furnace dust for reintroduction into the agglomeration process
}

\author{
Vasilica Viorica Toniţăă ${ }^{1, *}$, Geta Cârâc ${ }^{2}$ and Virgil Gabriel Teodor ${ }^{3}$ \\ ${ }^{1}$ Faculty of Materials Engineering and the Environment, University „Dunărea de Jos” Galati, România \\ ${ }^{2}$ Faculty of Science and Environment University „Dunărea de Jos” Galati, România \\ 3 Faculty of Mechanical, University „Dunărea de Jos” Galati, Domneasca Street, 47, 800008 - Galati, România
}

\begin{abstract}
Significant amounts of dust from the processing of cast iron in the furnace can be considered as by-products for the technological flow from the agglomeration, having an adequate chemical and structural composition. Blast furnace dust contains significant amounts of metals and non-metals that can be recovered by various processing methods. The transformation of these recyclable materials for reuse into metal producing units is essential not only for the conservation of mineral resources but also for the protection of the environment. This paper presents the chemical and mineralogical characterization of blast furnace dust resulting from the processing of cast iron, a useful analysis for this material to be reintroduced into the agglomeration process. From the obtained results it was found that the blast furnace dust contains significant amounts of $\mathrm{SiO}_{2}$ in fine granular form $(<1 \mathrm{~mm})$ which determines a fluidization of the slag resulting from the production of cast iron in the blast furnace, as well as the fact that it helps to form the binder phases in the agglomerate due to the fact that the powders have a high thermo-chemical activity that can be considered a first phase of formation of the initial liquid melt that triggers the reaction between melt and solid.
\end{abstract}

Keywords: blast furnace dust, agglomeration, composition, structure

*Corresponding author: tonitaviorica@gmail.com 


\section{Introduction}

In metallurgical processes, blast furnace dust is a mixture of dust collected from the electrostatic precipitators that serve the blast furnace bunkers, from the blast furnace gas discharge chimney and from the blast furnace treatment plant with cyclone and dust bag. Blast furnace dust is a waste that can be used successfully in the agglomeration process due to its mineral content [1-5].

Large amounts of dust are generated in the metallurgical industry and studies show current concerns for finding new solutions to capitalize on this mineral-rich material. Determining the chemical composition of blast furnace dust is very important in order to identify valuable and unwanted elements, which are involved in the collection, transport and storage of waste, and to adapt recovery technologies [1]. Studies indicate that in the agglomeration process blast furnace dust can be used successfully if the optimal parameters for the technical laboratory equipment are established and if the method established by Dr. Fernand Claisse is applied [6]. The presence of $\mathrm{Al}_{2} \mathrm{O}_{3}$ is very important both in the structure of the agglomerate and in the structure of the materials that make up the batch because it has an essential role in the formation of SFCA (complex ferrites of calcium, aluminium and silicon). Research has shown that SFCA does not form at $1275^{\circ} \mathrm{C}$ if $\mathrm{Al}_{2} \mathrm{O}_{3}$ is below $1 \%$.

For a constant $\mathrm{SiO}_{2}$ content and a known basicity index, $\mathrm{Al}_{2} \mathrm{O}_{3}$ initiates the formation of complex aluminium ferrites (SFCA) and stabilizes them, and the stability increases with increasing temperature and $\mathrm{Al}_{2} \mathrm{O}_{3}$ content [2]. Studies by some researchers have shown that to improve the fluidity of slag and reduce the silicon content of cast iron, materials containing $\mathrm{SiO}_{2}$ in fine granular form $(<1 \mathrm{~mm})$ can be introduced into the sintering mixture, this granulation being much more accepted because the silica with high granulation in some ores does not react during sintering, this being found in the ferrous agglomeration [2-5]. The properties of an agglomerate are conditioned not only by the mass of assimilated ore but also by the bonding phases and the chemical composition of the raw and secondary materials. As the binder phases reach about $80 \%$ of the total volume of the agglomerate, and of these $50 \%$ represent the complex phases of SFCA, it can be deduced that the furnace powders, once introduced in the formation of the stack and the batch, respectively, have a significant influence on the quality of the agglomerate by forming the phases in the agglomerate. Our study presents the chemical analysis of the composition of the blast furnace dust and the structural and morphological characterization, as well as the changes obtained by the melting process.

By knowing the chemical composition, it is possible to choose the process and technology of recovery (recycling) that makes it possible to transfer blast furnace dust from the category of waste to the category of by-products or secondary raw materials.

\section{Experiment}

Dust samples were taken from the furnace bunkers in the amount of $500 \mathrm{~g}$, samples that were well homogenized and, at the same time, aliquot samples were performed in numbers of 5 to $1 \mathrm{~g}$ each.

Equal quantities of the samples taken were subjected to the agglomeration process in an infrared (IR) combustion furnace - type VULCAN - Fusion Technology, using the melting method according to the fusion technique established by Dr. Fernand Claisse [6]. The process of processing samples in the combustion furnace is similar to the sintering process in the agglomeration machine. Semi-quantitative analysis of the compounds in the samples was performed using a binder - lithium tetraborate in an amount 10 times higher than the amount of sample used.

Elemental X-ray fluorescence (XRF) analysis was used to determine the chemical composition of the samples on a Brucker S8 Tiger X-ray fluorescence spectrometer and the structural analysis using the Panalytical X'Pert modular system PRO-Materials Research Diffractometers (MRD) diffractometer, devices belonging to the Center for Ecometallurgical Research and Expertise within the Politehnica University of Bucharest).

The morphological analysis was performed using the scanning electron microscopy (SEM) technique at the Quanta Inspect F scanning electron microscope (University of Galati).

\section{Results and discussion}

The blast furnace dust taken to determine the chemical, morphological and structural composition was analyzed and processed by melting, according to the fusion technique established by Dr. Fernand Claisse [6]. Technology schema of the recovery of blast furnace into ferrous agglomerate is shown in schema 1.

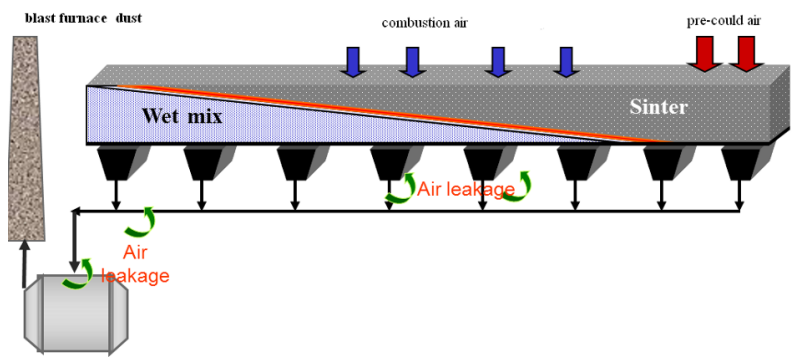

Schema 1 . Technology of recovery of blast furnace dust 


\subsection{Compositional analysis}

Knowledge of the chemical composition is important in the agglomeration process for the subsequent recovery of the resulting material [7-10].

In the histogram of Fig. 1 shows the semiquantitative percentage analysis of the important compounds in the blast furnace dust sample.

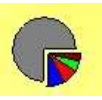

Fig. 1. Semi-quantitative percentage analysis of blast furnace dust

To obtain an agglomerate with high reducibility and high mechanical strength, the batch must contain at least $2-3 \%$ of $\mathrm{Al}_{2} \mathrm{O}_{3}$, which demonstrates that the contribution of blast furnace dust is significantly profitable because they are raw materials obtained from the internal technological flow and have a high content of $\mathrm{Al}_{2} \mathrm{O}_{3}$, as shown in Tab. 1. The indexing of the diffractogram obtained on the sample from the blast furnace dust reveals 5 chemical phases, in a high percentage of $74 \%$ being $\left.\mathrm{Mg}_{0,57} \mathrm{Fe}_{0,43}\right)_{2}\left(\mathrm{Al}_{4} \mathrm{Si}_{5} \mathrm{O}_{18}\right)$, and $\mathrm{Al}_{2} \mathrm{O}_{3}$ is in a percentage of $5 \%$ [8].

Table 1. Analysis of distinct phases in blast furnace dust

\begin{tabular}{|c|c|c|c|}
\hline $\begin{array}{c}\text { Chemical } \\
\text { phase }\end{array}$ & $\begin{array}{l}\text { Crystal } \\
\text { structure }\end{array}$ & $\begin{array}{c}2 \theta \\
(\max .)\end{array}$ & $\%$ \\
\hline \multirow{2}{*}{$\begin{array}{l}1 . \mathrm{Mg}_{0,57} \mathrm{Fe} \\
0,43)_{2}\left(\mathrm{Al}_{4} \mathrm{Si}\right. \\
\left.{ }_{5} \mathrm{O}_{18}\right)\end{array}$} & \multicolumn{3}{|c|}{$\begin{array}{l}\text { tetraluminate -tectopentasilicate of iron and } \\
\text { magnesium }\end{array}$} \\
\hline & $\begin{array}{l}\text { orthorhom } \\
\text { bic }\end{array}$ & $10.42^{0}$ & 74 \\
\hline $\begin{array}{l}\text { 2. } \mathrm{Fe}_{2} \mathrm{O}_{3} \\
\text { hematite }\end{array}$ & $\begin{array}{l}\text { rhombohed } \\
\text { ral }\end{array}$ & $33.18^{0}$ & 9 \\
\hline $\begin{array}{l}3 . \mathrm{SiO}_{2} \\
\text { silicon } \\
\text { oxide } \\
\end{array}$ & hexagonal & $26.41^{0}$ & 8 \\
\hline $\begin{array}{l}4 . \mathrm{Al}_{2} \mathrm{O} 3 \\
\text { aluminum } \\
\text { oxide }\end{array}$ & $\begin{array}{l}\text { orthorhom } \\
\text { bic }\end{array}$ & $51.88^{0}$ & 5 \\
\hline $\begin{array}{l}\text { 5. } \mathrm{Ca} \\
\text { calcium }\end{array}$ & hexagonal & $29.21^{0}$ & 4 \\
\hline
\end{tabular}

To identify the elements in the composition, both for the blast furnace dust and for the ferrous agglomerate sample, the elemental analysis by $\mathrm{X}$-ray fluorescence was performed. (Tab. 2).

Metallic elements are present in both analyzed samples, generally with the modification of the percentages in the chemical composition.

Iron is higher in quantity, and about 2 times higher in ferrous agglomerate (71.22\%) compared to blast furnace dust (34.11\%).

Calcium and silicon showed a slight increase of $2.33 \%$ for calcium and $0.15 \%$ for silicon, respectively.
The other identified elements, such as $\mathrm{Al}, \mathrm{Mn}, \mathrm{P}$, $\mathrm{K}, \mathrm{Ti}, \mathrm{S}, \mathrm{Zn}, \mathrm{Cr}$ and $\mathrm{Cu}$, are in smaller quantities in the resulting ferrous agglomerate compared to the blast furnace dust. $\mathrm{Zn}$ and $\mathrm{Cr}$ are about 10 times higher in blast furnace dust compared to ferrous agglomerate.

Table 2. Elemental composition of blast furnace dust and ferrous agglomerate

\begin{tabular}{|c|c|c|}
\hline $\begin{array}{c}\text { Chemical } \\
\text { element }\end{array}$ & $\begin{array}{c}\text { Blast furnace } \\
\text { dust (\%) }\end{array}$ & $\begin{array}{c}\text { Agglomerate } \\
\text { ferrous (\%) }\end{array}$ \\
\hline $\mathrm{Fe}$ & 34.11 & 71.22 \\
\hline $\mathrm{Ca}$ & 7.44 & 9.77 \\
\hline $\mathrm{Si}$ & 5.07 & 5.15 \\
\hline $\mathrm{Mg}$ & 1.96 & 1.79 \\
\hline $\mathrm{Al}$ & 1.60 & 0.94 \\
\hline $\mathrm{Mn}$ & 0.99 & 0.35 \\
\hline $\mathrm{P}$ & 0.71 & 0.19 \\
\hline $\mathrm{K}$ & 0.41 & 0.08 \\
\hline $\mathrm{S}$ & 0.33 & 0.06 \\
\hline $\mathrm{Ti}$ & 0.20 & 0.05 \\
\hline $\mathrm{Zn}$ & 0.19 & 0.02 \\
\hline $\mathrm{Cr}$ & 0.18 & 0.02 \\
\hline $\mathrm{Cu}$ & 0.13 & $76 \mathrm{ppm}$ \\
\hline
\end{tabular}

\subsection{Determining the compositional phases}

An important stage in the analysis of the materials used for recovery is the mineralogical analysis, because the component elements of the materials used in the agglomeration process can be combined into several minerals with different crystalline structures that can interact with each other, preventing or accentuating the formation of carbonates following the agglomeration process [9 14].

The components of blast furnace dust are grouped into different types of minerals, some can form carbonates $(\mathrm{CaO}$ and $\mathrm{MgO})$ and others require high temperature and pressure conditions (e.g. $\left(\mathrm{Mg}_{0,57} \mathrm{Fe}_{0,43}\right)_{2}\left(\mathrm{Al}_{4} \mathrm{Si}_{5} \mathrm{O}_{18}\right)$ as well as various minerals that do not form carbonates as a result of the melting / sintering process (e.g. $\mathrm{SiO}_{2}$ ). The resulting minerals in the samples and their behavior as a result of the sintering process can be determined by X-ray diffraction analysis, followed by quantitative analysis of minerals. Figure 3 shows the diffractograms obtained for the two samples, the blast furnace dust and the ferrous agglomerate sample. 

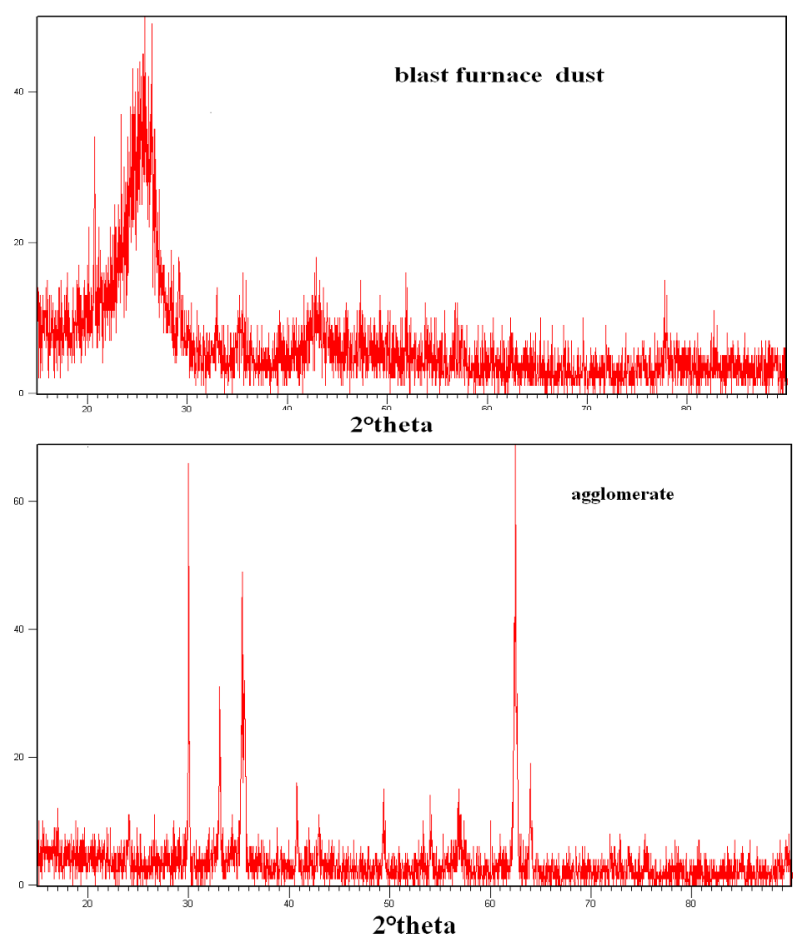

Fig. 2. X-ray diffractogram for blast furnace dust and ferrous agglomerate samples

Different mineralogical changes can be observed that occur as a result of the agglomeration process, more important being the change up to $500(2 \theta)$.

The first region is attributed to the amorphous state, the presence of $\mathrm{SiO}_{2}$, but which is observed only in the composition of the blast furnace dust. $\mathrm{SiO}_{2}$ is in fine granular form $(<1 \mathrm{~mm})$ which determines a fluidization of the slag resulting from the production of cast iron in the blast furnace. The following region provides details about the proportion of iron-based minerals and metal oxides where one can easily observe the large difference between the amount of iron present in the ferrous agglomerate compared to that present in the furnace dust.

The last region includes component mineral phases whose quantity is negligible and unimportant for the purpose of our research.

\subsection{Morphological analysis}

The structural changes suffered by the materials subjected to different melting processes can be highlighted by morphological analysis using scanning electron microscopy (SEM) [10].

Samples of blast furnace dust and those resulting from the melting process were examined without the need for special preparation. For an overview of the component particles, magnifications of 1000X and 2000X were used.
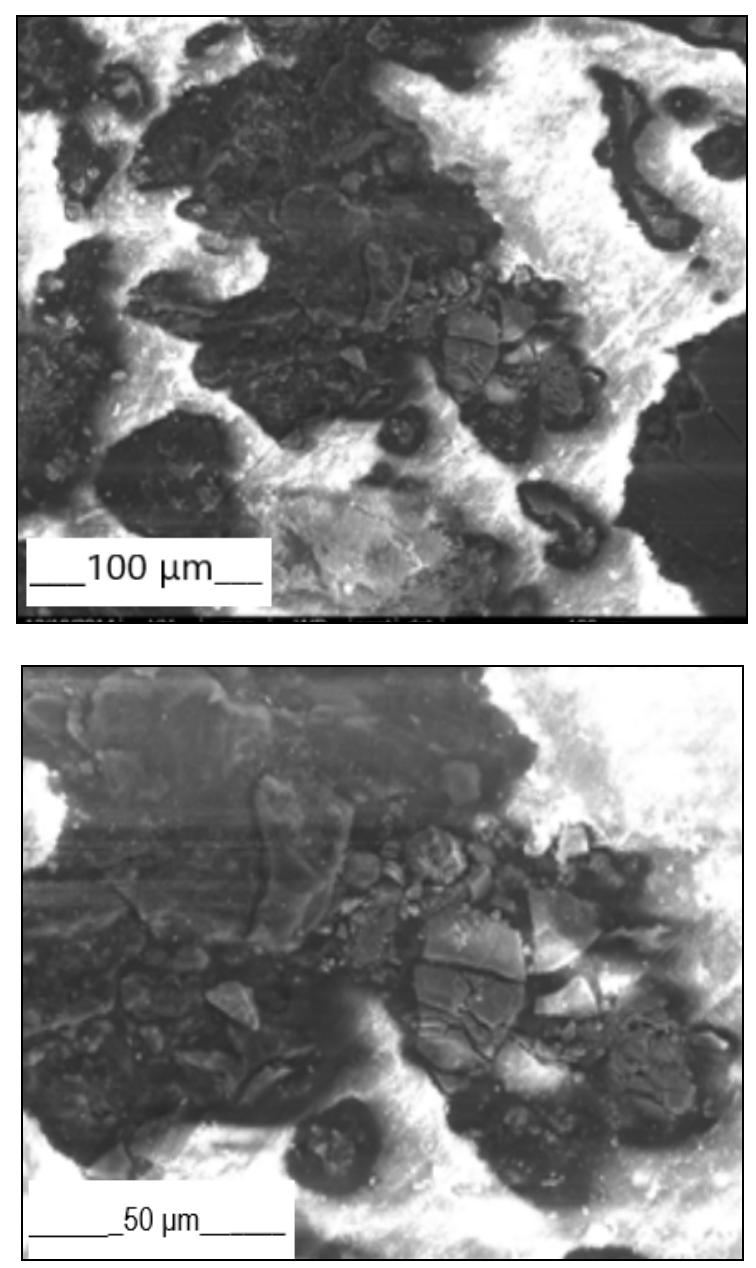

Fig. 3. SEM images - Morphology of the blast furnace dust

From the morphological analysis of blast furnace dust and ferrous agglomerate, several aspects can be highlighted, namely the blast furnace dust samples belong to the layer of fine, adherent particles characterized as having the highest thermo-chemical activity in the melting process.

This characteristic can be considered as a first phase of formation of the initial liquid melt which triggers the reaction between the melt and the solid.

Fig. 4 shows the morphology of the ferrous agglomerate sample at the same magnifications as for the blast furnace dust sample represented in Fig. 3 .

The SEM images show a different shape of the component particles, larger granular particles in the blast furnace dust compared to those in the ferrous agglomerate sample.

At the same time, there was an obvious difference between the agglomerate and the blast furnace dust by the number of larger particles in the case of the agglomerate. Also, another notable difference is the shape of the particle edges of the components for the agglomerate, which are sharper than in the blast furnace dust samples. 

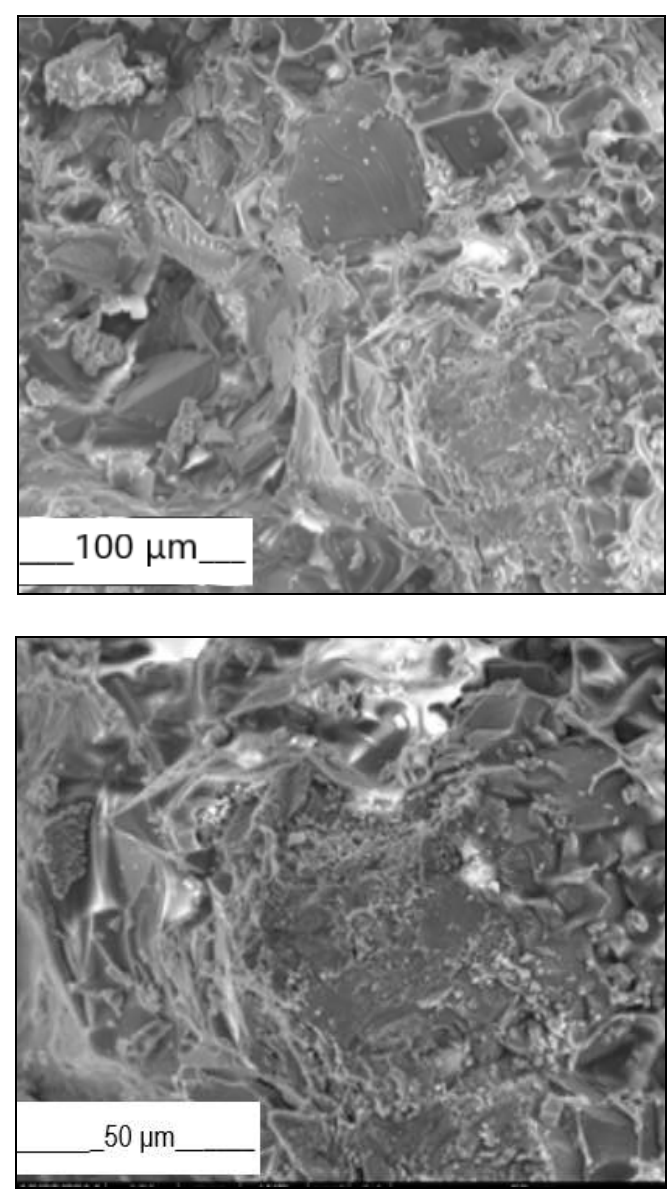

Fig. 4. SEM images - Morphology of the ferrous agglomerate

\section{Conclusions}

Samples of blast furnace dust and ferrous agglomerate were analyzed to highlight the role and importance of distinct elements in the melting / sintering process. Five chemical phases were confirmed in the blast furnace dust sample in which the presence of $\mathrm{Al}_{2} \mathrm{O}_{3}$ is higher than $2-3 \%$ which leads to the formation of complex ferrite of calcium, aluminium and silicon during the sintering process from the agglomeration machine.

Iron is the metal with the highest presence in blast furnace dust and with double value in ferrous agglomerate. The structural analysis confirms the differences in the sample of ferrous agglomerate and the sample of blast furnace dust with the contribution of $\mathrm{SiO}_{2}$ which is mainly found in blast furnace dust.

The obtained results confirm the usefulness of blast furnace dust as a by-product in obtaining the ferrous agglomerate, to limit it considering as waste.

\section{References}

1. A. Ciocan, Valorificarea deşeurilor metalurgice. Procese şi tehnologii, Galaţi University Press (2008) 2. N. A. El-Hussiny, M. E. H. Shalabi, SCI SINTER 42, 269-281 (2010)

2.X.Xiao, S.Zhang, F Sher, et al. A Review on Recycling and Reutilization of Blast Furnace Dust as a Secondary Resource. J. Sustain. Metall. 7, 340-357 (2021).

3. P. K. Singh, A. L. Kumar, R., Kr Rai, S. Srivastava, Recycling of Environmentally Hazardous Wastage of Integrated Steel Plants, in International Conference on Integrated Waste Management and Green Energy Engineering, Johannesburg, South Africa d April 15-16 (2013)

4. A.V. Socalici, E. Ardelean, M.L. Strugariu, Env. Eng. Managem. J. (EEMJ), 15, 207-212 (2016)

5. D. Mombelli, D.L. Gonçalves, C. Mapelli, et al. Processing and Characterization of Self-Reducing Briquettes Made of Jarosite and Blast Furnace Sludges. Journal Sustainable. Metallurgy (2021). https://doi.org/10.1007/s40831-021-00419-2

6. C. Samson: Heterogenity effects in x-ray analysis. Adv-F Claisse - X-ray Anal (1962)

7. F. Engstrom, D. Adolfsson, C. Samuelsson, A. Sandstrom, B. Bjorkman, Miner. Eng. 41, 46-52 (2013)

8. N.P. Nayak, Characterization of blast furnace flue dust- assessment for its utilization, Materials Today: Proceedings(2021)https://doi.org/10.1016/j.matpr.2021. 09.417

9. D.C. Sahu, R. Murmu, P. Senapati, H. Sutar, Optimization of Raceway Parameters in Iron Making Blast Furnace for Maximizing the Pulverized Coal Injection (PCI) Rate, Advances in Chemical Engineering and Science 11 (02) (2021), ID:107520;13 pag. 10.4236/aces.2021.112009

10. I.D. Samusi, Analiza structurală. Metode difractometrice şi microscopice, Ed. Tehnică UTM, Chişinău (2006)

11. V. Suciu, M.V. Suciu, Studiul materialelor, Ed. Fair Partners, Bucureşti, (2007)

12. C. Gheorghieş, Analiza structurii fine a materialelor, Ed. Tehnică, Ştiinţifică şi Didactică CERMI, Iaşi (2007)

13. B. Das, S. Prakash, P.S.R. Reddz, S.K. Biswall, B.K. Mohapatra, V.N. Misra, Effective Utilization of Blast Furnace Flue Dust of Integrated Steel Plants, The European Journal of Mineral Processing and Environmental Protection, 2(2) 61-68 (2020)

14. V.V. Toniţă (Corcoţoi), M. Vlad, I. Severin, A. Berbecaru, Advanced Materials Research 1143, 120126 (2017) 